\title{
Bio-Inspired Ni(II) Porphyrin Dimers with a Bridging Diphenyl Moiety: Facile Synthesis and Molecular Inherent Chirality
}

\author{
Xu Liang, ${ }_{1}^{\mathrm{a}, \mathrm{b} @ 1}$ Honglin Zhang, ${ }^{\mathrm{a}}{ } \mathrm{He} \mathrm{Luo}_{1}{ }^{\mathrm{a}}$ Mingfeng Qin, ${ }^{\mathrm{a}, \mathrm{b}}$ Minzhi Li, ${ }^{a}$ \\ and Weihua Zhu ${ }^{\mathrm{a}, \mathrm{b} @ 2}$ \\ ${ }^{a}$ School of Chemistry and Chemical Engineering, Jiangsu University, 212013 Zhenjiang, P. R. China \\ ${ }^{\mathrm{b}}$ State Key Laboratory of Coordination Chemistry, Nanjing University, 210000 Nanjing, P. R. China \\ ${ }^{\circledR 1}$ Corresponding author E-mail: liangxu@ujs.edu.cn \\ ${ }^{\circledR 2}$ Corresponding authorE-mail: sayman@ujs.edu.cn
}

Porphyrin dimers with amide-bonded 2,2'- and 4,4'-biphenyl moieties were synthesized and isolated. Both structural and spectroscopic characterizations were performed to in-depth understand the relationship between the helical molecular structure and inherent chirality of achiral 2,2'-biphenyl linked flexible porphyrin dimers.

Keywords: Porphyrin dimer, molecular chirality, electronic structure, spectroscopy.

\section{Биоинспирированные димеры порфирината Ni(II) с Аифенильным мостиком: легкий синтез и молекулярная хиральность}

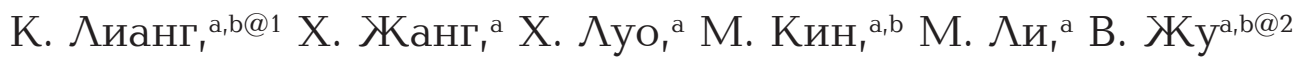 \\ аШкола химии и химической инженерии, Университет Цзянсу, 212013 Чжэньцзян, Китай \\ 'Государственная ключевая лаборатория координационной химии, Нанкинский университет, 212013 Нанкин, Китай \\ ${ }^{\circledR 1}$ E-mail: liangxu@ujs.edu.cn \\ @2E-mail:sayman@ujs.edu.cn
}

\begin{abstract}
В данной работе синтезированы и выделены димеры порфирина с амидосвязанными 2,2'- и 4,4'-бифенильными фрагментами. Для более глубокого понимания взаимосвязи между спиральной структурой молекул и хиральностью ахиральных гибких димеров порфирина с 2,2'-бифенильнылм мостиком были получены как структурные, так и спектральные характеристики.
\end{abstract}

Ключевые слова: Димер порфирина, молекулярная хиральность, электронная структура, спектроскопия.

\section{Introduction}

As the key components in human genes and proteins, amino acids, the natural organic compounds containing amine $\left(-\mathrm{NH}_{2}\right)$ and carboxyl $(-\mathrm{COOH})$ functional groups along with a side chain ( $\mathrm{R}$ group) specific to each amino acid, have a great importance in life processes..$^{[1-2]}$ Also, reactions between chiral amine and carboxyl derivatives which forming amide-bonds that repeat the basic chemical processes of protein four-level construction. ${ }^{[3-4]}$ In addition, chirality has been the subject of ongoing research interest in the pharmacy, food, and chemicals industries. ${ }^{[5-6]}$ As an important branch of chiral molecules, chiral porphyrin is forming a growing multidisciplinary field because of its importance in various natural processes, such as photosynthesis, biomolecular redox catalysts, and chiral molecule recognition. ${ }^{[7-8]}$ Within this purpose, synthetic chiral porphyrins provide more possibilities for forming new smart material technologies due to their novel molecular structures. Chiral porphyrin could be easily received through the incorporation of intrinsically chiral meso-ABCD-typesubstituents, ${ }^{[9]}$ and unsymmetrical "single-armed" distorted 
porphyrins. ${ }^{[10]}$ Moreover, introduction of inherently chiral linkages, chiral extensions like through functional chiral substituents, decrease molecular symmetry through coordination, the multi-porphyrins arranged in a cycle and/or cage manner. ${ }^{[11-12]}$ On the other hand, in chemistry, inherent chirality is a property of asymmetry in molecules arising, not from a stereogenic or chiral center, but from a twisting of the molecule in 3D space. From this point of view, much considerable attention has been paid to the preparation, characterization, and application of chiral molecules arising from their helical structures, whose helical main chains are potentially interconvertible to the mirror image helical structure. ${ }^{[13-14]}$ In addition to the helical molecules supported by chiral stereogenic centers in their main chains, such as triphenylmethyl methacrylates and polysilanes, those devoid of stereogenic centers, such as polyacetylenes, polyisocyanates, and polyisocyanides, are known and have attracted increasing attention. ${ }^{[15-16]}$ In the field of porphyrin and phthalocyanine, inherent chirality also plays important roles for porphyrinoids to reveal several novel molecular structure and spectroscopic properties. ${ }^{[17-18]}$ As an ideal candidate, porphyrinoids containing chiral BINOL (1,1'-bi2-naphthol) units were widely used to investigate inherent chirality based on the steric hindrance of two naphthene rings. ${ }^{[19-20]}$ Herein, we consider using biphenyl as a linkage, the reduced steric hindrance from BINOL derivatives, that the molecular inherent chirality may by defined by the arrangement of $2^{\text {nd }}$ chromophores, such as amidebonded porhyrinoids.

\section{Experimental}

\section{Materials and Equipment}

All chemicals and reagents were commercial analytical pure grade for organic synthesis and spectroscopic pure for all measurements. MALDI-TOF-mass measurements were recorded on a Bruker Daltonics solari X working station. ${ }^{1} \mathrm{H}$ NMR spectra were recorded on a Bruker AVANCE 400 spectrometer (operating at $400.13 \mathrm{MHz}$ ) using the residual solvent as an internal reference for $1 \mathrm{H}\left(7.26 \mathrm{ppm}\right.$ for $\left.\mathrm{CDCl}_{3}\right)$. UV-Visible absorption spectra were recorded with a HP 8453A diode array spectrophotometer. Circu- lar dichroism (MCD) spectra were measured with a JASCO J-820 equipment.

\section{Synthesis}

5-p-Aminophenyl-10,15,20-triphenylporphyrin (1). Nitrosonitric acid $(3.2 \mathrm{~mL})$ was slowly added to $300 \mathrm{~mL}$ of $\mathrm{CH}_{2} \mathrm{Cl}_{2}$ solution of 5,10,15,20-tetrahenylporphyrin $(3.00 \mathrm{~g}, 4.88 \mathrm{mmol})$, and the mixture was stirred at $0-5^{\circ} \mathrm{C}$ in an ice-bath for $4 \mathrm{~h}$. The reaction mixture was neutralized with ammonia solution to $c a$. $\mathrm{pH} 7.0$, and the organic layer was washed with brine and dried with anhydrous $\mathrm{MgSO}_{4}$. After removal of the solvent, the residue was recrystallized from $\mathrm{CH}_{2} \mathrm{Cl}_{2}$ and $\mathrm{MeOH}$ and finally purified by $\mathrm{Al}_{2} \mathrm{O}_{3}$ gel chromatography (eluent: $\mathrm{CH}_{2} \mathrm{Cl}_{2} /$ hexane=2:1) to give 5-p-nitrophenyl-10,15,20-triphenylporphyrin as a purple solid. $\mathrm{SnCl}_{2} \cdot 2 \mathrm{H}_{2} \mathrm{O}(2.0 \mathrm{~g}, 1.62 \mathrm{mmol})$ was then added to a $100 \mathrm{~mL}$ conc. $\mathrm{HCl}$ solution of 5-p-nitrophenyl-10,15,20-triphenylporphyrin $(916 \mathrm{mg}, 0.400 \mathrm{mmol})$. The mixture was vigorously stirred in a preheated oil bath $70{ }^{\circ} \mathrm{C}$ for $2 \mathrm{~h}$, and then neutralized to around $\mathrm{pH} 8.0$ with ammonia solution. The reaction mixture was quenched by $50 \mathrm{~mL}$ ice-water and the water phase was extracted with ethylacetate $(3 \times 100 \mathrm{~mL})$. The combined organic layers were dried with anhydrous $\mathrm{MgSO}_{4}$. After removal of the organic solvent, the residue was purified through recrystallization by adding $\mathrm{MeOH}$ to the $\mathrm{CH}_{2} \mathrm{Cl}_{2}$ solution to afford pure 5-p-aminophenyl-10,15,20-triphenylporphyrin $\mathbf{1}$ as a purple solid in $87.3 \%$ yield $(767 \mathrm{mg}) .{ }^{1} \mathrm{H}$ NMR $\left(\mathrm{CDCl}_{3}, 298 \mathrm{~K}\right) \delta_{\mathrm{H}} \mathrm{ppm}$ : $8.93(\mathrm{~d}, J=4.0 \mathrm{~Hz}, 2 \mathrm{H}), 8.84$ (s, 6H), 8.20 (d, $J=8.0 \mathrm{~Hz}, 2 \mathrm{H}), 7.98$ (d, $J=8.0 \mathrm{~Hz}, 2 \mathrm{H}), 7.74 \sim 7.80(\mathrm{~m}, 9 \mathrm{H}), 7.06(\mathrm{~d}, J=8.0 \mathrm{~Hz}, 2 \mathrm{H}), 4.02$ (s, 2H), -2.76 (s, 2H).

Synthesis of cis-1. 2,2'-Biphenyldicarboxylic acid $(24.2 \mathrm{mg}$, $0.1 \mathrm{mmol})$ and excess $\mathrm{SOCl}_{2}(5 \mathrm{~mL})$ were refluxed at $90{ }^{\circ} \mathrm{C}$ for $2 \mathrm{~h}$, and the $\mathrm{SOCl}_{2}$ was removed under distillation. The residue was then dissolved in $20 \mathrm{~mL}$ of dry $\mathrm{CH}_{2} \mathrm{Cl}_{2}$ and 5- $p$-aminophenyl-10,15,20-triphenylporphyrin was added $(152.0 \mathrm{mg}, 0.22 \mathrm{mmol}$, 1:2.2) and the mixture was stirred at $0{ }^{\circ} \mathrm{C}$ in the dark for about $1 \mathrm{~h}$, with the reaction carefully monitored by TLC plate. When the solvent was removed, further purification by silica gel column chromatography and GPC-packed bio-beads column (sx-8) provided the target $\mathrm{Ni}(\mathrm{II})$ porphyrin dimer cis-1 as a pure red solid in $8.1 \%$ yield (12.9 mg). Found: C 77.76, H 4.15, N 8.78, O $2.03 \%$. Calcd.: C 77.70, H 4.12, N 8.80, O $2.01 \%$. MALDI-TOF $m /$ $z=1592.266$ (Calcd. $\left.[\mathrm{M}]^{+}=1592.108\right) .{ }^{1} \mathrm{H}$ NMR $\left(400 \mathrm{MHz}, \mathrm{CDCl}_{3}\right)$ $\delta_{\mathrm{H}}$ ppm: $9.37(2 \mathrm{H}, \mathrm{s}), 8.75-8.70(16 \mathrm{H}, \mathrm{m}), 8.10-7.97(12 \mathrm{H}, \mathrm{m}), 7.91$ $(6 \mathrm{H}, \mathrm{d}, J=8.4 \mathrm{~Hz}), 7.85(4 \mathrm{H}, \mathrm{d}, J=8.6 \mathrm{~Hz}), 7.69-7.62(18 \mathrm{H}, \mathrm{m}), 7.58$ $\left(4 \mathrm{H}, \mathrm{t}, J_{1}=3.9 \mathrm{~Hz}, J_{2}=4.0 \mathrm{~Hz}\right), 7.41-7.39(2 \mathrm{H}, \mathrm{m})$.

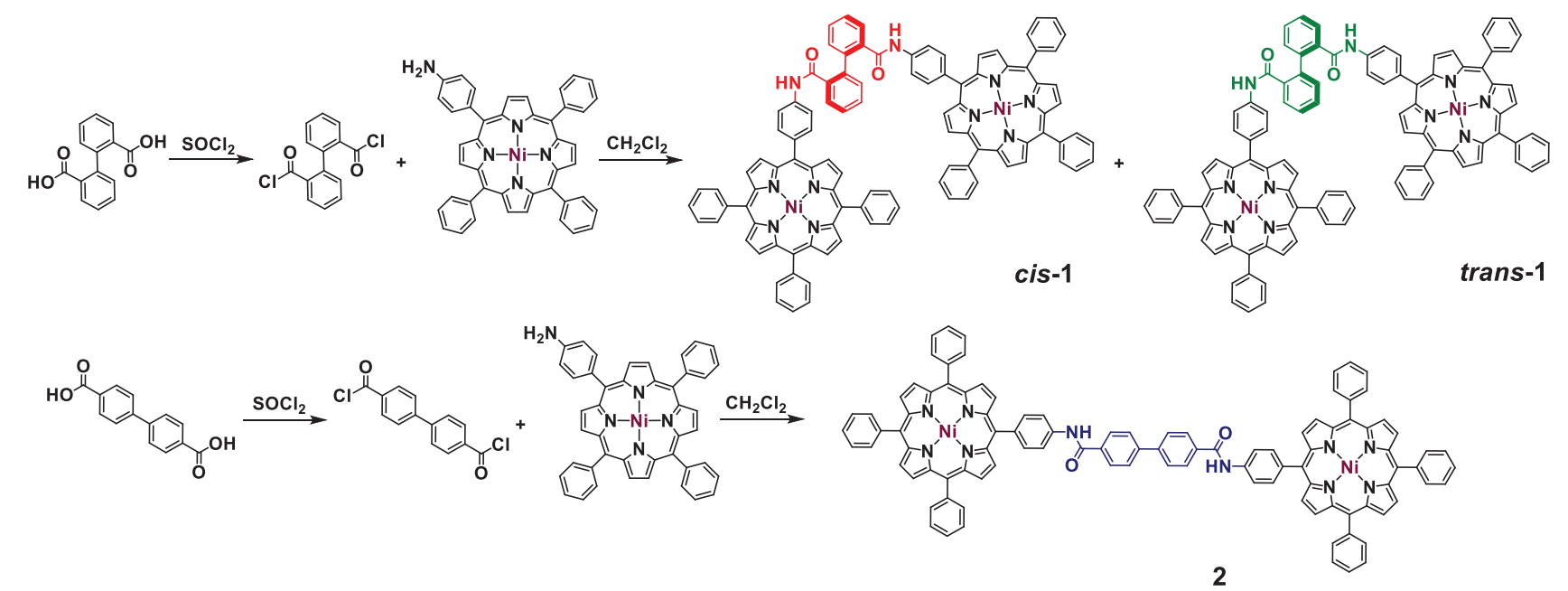

Scheme 1. Synthesis of porphyrin dimer containing amide-bonded 2,2- and 4,4'-diphenyl moiety. 
Synthesis of trans-1. Trans-1 was isolated from the reaction mixture that of synthesis of cis-1, and the target compound was obtained in a $33.5 \%$ yield (53.3 mg). Found: C 77.78, H 4.19, N 8.72 , O $2.05 \%$. Calcd. C 77.70, H 4.12, N 8.80, O $2.01 \%$. MALDITOF $m / z=1592.375\left(\right.$ Calcd. $\left.[\mathrm{M}]^{+}=1592.108\right) .{ }^{1} \mathrm{H}$ NMR $(400 \mathrm{MHz}$, $\left.\mathrm{CDCl}_{3}\right) \delta_{\mathrm{H}}$ ppm: $8.98(1 \mathrm{H}, \mathrm{d}, J=11.2 \mathrm{~Hz}), 8.77-8.72(18 \mathrm{H}, \mathrm{m}), 8.49$ $(1 \mathrm{H}, \mathrm{d}, J=1.2 \mathrm{~Hz}), 8.07$ (1H, d, $J=11.6 \mathrm{~Hz}), 8.02-7.99(14, \mathrm{~m}), 7.95$ $(3 \mathrm{H}, \mathrm{d}, J=8.4 \mathrm{~Hz}), 7.79(3 \mathrm{H}, \mathrm{d}, J=8.4 \mathrm{~Hz}), 7.72-7.64(20 \mathrm{H}, \mathrm{m}), 7.60$ $(1 \mathrm{H}, \mathrm{s}), 7.38(2 \mathrm{H}, \mathrm{d}, J=8.4 \mathrm{~Hz})$.

Synthesis of 2 . The general synthesis and purification procedures are the same as that of cis-1, only 4,4'-biphenyldicarboxylic acid was used instead, and the target compound was obtained in a $71.8 \%$ yield $(114.3 \mathrm{mg})$. Found: $\mathrm{C} 77.77, \mathrm{H} \mathrm{4.10,} \mathrm{N} \mathrm{8.80,} \mathrm{O}$ $2.00 \%$. Calcd.: C 77.70, H 4.12, N 8.80, O $2.01 \%$. m/z 1592.108 (Calcd. $\left.[\mathrm{M}]^{+}=1592.108\right) .{ }^{1} \mathrm{H}$ NMR $\left(400 \mathrm{MHz}, \mathrm{CDCl}_{3}\right) \delta_{\mathrm{H}}$ ppm: 8.98 $(1 \mathrm{H}, \mathrm{d}, J=11.2 \mathrm{~Hz}), 8.77-8.72(18 \mathrm{H}, \mathrm{m}), 8.50(1 \mathrm{H}, \mathrm{s}), 8.05(1 \mathrm{H}, \mathrm{d}$, $J=6.0 \mathrm{~Hz}), 8.02-7.99(14 \mathrm{H}, \mathrm{m}), 7.95(3 \mathrm{H}, \mathrm{d}, J=8.4 \mathrm{~Hz}), 7.79(3 \mathrm{H}, \mathrm{d}$, $J=8.4 \mathrm{~Hz}), 7.71-7.64(20 \mathrm{H}, \mathrm{m}), 7.56(1 \mathrm{H}, \mathrm{s}), 7.39(2 \mathrm{H}, \mathrm{d}, J=8.4 \mathrm{~Hz})$.

\section{Results and Discussion}

The preparation and isolation of chiral porphyrin dimers cis-1, trans-1 and $\mathbf{2}$ followed bio-inspired procedures. The reaction between $\mathrm{Ni}(\mathrm{II})-5$ - $p$-aminophenyl-10,15,20triphenylporphyrin and 2,2'- (or 4,4'-) biphenyldicarboxylic acid provides the diphenyl linked $\mathrm{Ni}(\mathrm{II})$ porphyrin dimers and containing its diastereomers. It should be mentioned here when $\mathrm{SOCl}_{2}$ was used during the reaction, both trans-1 and $\boldsymbol{c i s}-1$ could be obtained and isolated in an approximately 1:4 ratio. In contrast, when dicyclohexylcarbodiimide (DCC) was used as the dehydration reagent, only trans-1 isomer obtained as a sole product in the much lower yield. The overall yield of the porphyrin dimer 2 (Scheme 1) that is prepared using 4,4'-biphenyldicarboxylic acid is significantly higher than for those obtained with 1,2'-biphenyldicarboxylic acid probably because of steric hindrance that are encountered with the latter. Based on the MALDI-TOF MS measurements, a strong parent peaks were observed for porphyrin trans-1 at $\mathrm{m} / \mathrm{z}=1592.266$ (Calcd. $[\mathrm{M}]^{+}=1592.108$ ), and similar peaks were clearly observed in the case of cis-1 and 2. The ${ }^{1} \mathrm{H}$ NMR spectra of these porphyrin dimers are typical to those obtained for $\mathrm{Ni}(\mathrm{II})$ porphyrins with several peaks at lower field due to the aromaticity of the porphyrin rings and the bridging diphenyl moiety. In Figure 1, cis-1 isomer reveals clear singlet peak at $\delta=9.37 \mathrm{ppm}$ that was similar with other flexible amide-bonded Ni(II)porphyrin dimer arranged in a faceto-face manner. ${ }^{[2]}$ In contrast, the ${ }^{1} \mathrm{H}$ NMR data of trans-1 and $\mathbf{2}$ are quite similar, but different from cis-1 isomer because of two porphyrin rings were arranged in a more flexible manner. ${ }^{[1,22]}$ The difference observed for the ${ }^{1} \mathrm{H}$ NMR spectra could be assigned as the internal steric hinderance and hydrogen bonding interaction, which was widely observed in the multi-amide bonded molecules and even natural proteins. As reported, when metallo-porphyrin dimers containing achiral linkage, the single molecule doesn't have mirror symmetry, but has rotational symmetry, which leads to a porphyrin dimer arranged as a defined twist. ${ }^{[22]}$ The angle between the projections of the electric transition moments could be modulated arising from the flexibility of amide-bonded and even functional building blocks, and the corresponding inter-transition angle could be much closer to the $70^{\circ}$ (the best angle for the coupling). ${ }^{[23]}$ In addition, when theoretical calculations were carried out on the $\mathrm{Zn}$ (II)porphyrin dimer complex, large separations were correctly predicted between the two porphyrin rings for different possible conformations of the flexible amide-linked derivatives, and hence there was no scope for a significant interaction between the rings. ${ }^{[2]}$ When $\mathrm{Ni}(\mathrm{II})$ porphyrin dimers were prepared containing both amidebond and functional building blocks, even when empirical dispersion corrections were applied, the smaller distance was preferable to predict the arrangement of the porphyrin rings in the B3LYP-optimized structures with lower molecular ground state. ${ }^{[21]}$ Thus, Ni(II)porphyrin dimers maybe the suitable candidates to simplify the current system to investigate the synthesis and properties of inherently chiral porphyrin dimers.

The UV-Visible absorption spectra of cis-1, trans-1 and $\mathbf{2}$ (Figure 2) are only slightly broader to those of the parent $\mathrm{Ni}(\mathrm{II})$ tetraphenylporphyrin (Ni(II)TPP), ${ }^{[24]}$ since there are minor changes in the relative energies of the frontier $\pi$-molecular orbitals ( $\pi$-MOs) due to the modification of one of the meso-phenyl rings and the flexible molecular structures. These compounds were not emitted due to transition metal coordination. The circular dichroism spectra of trans1, cis-1 and 2 (Figure 1) are consistent with an exciton between the two $\mathrm{Ni}(\mathrm{II})$ porphyrin rings that is associated with the relatively flexible bridging amide-bonded diphenylmoiety which were measured in highly diluted solution to confirm the molecular behavior. Since no chiral center was observed within the molecules, the chirality of these porphyrins could be assigned as the molecular inherent chi-
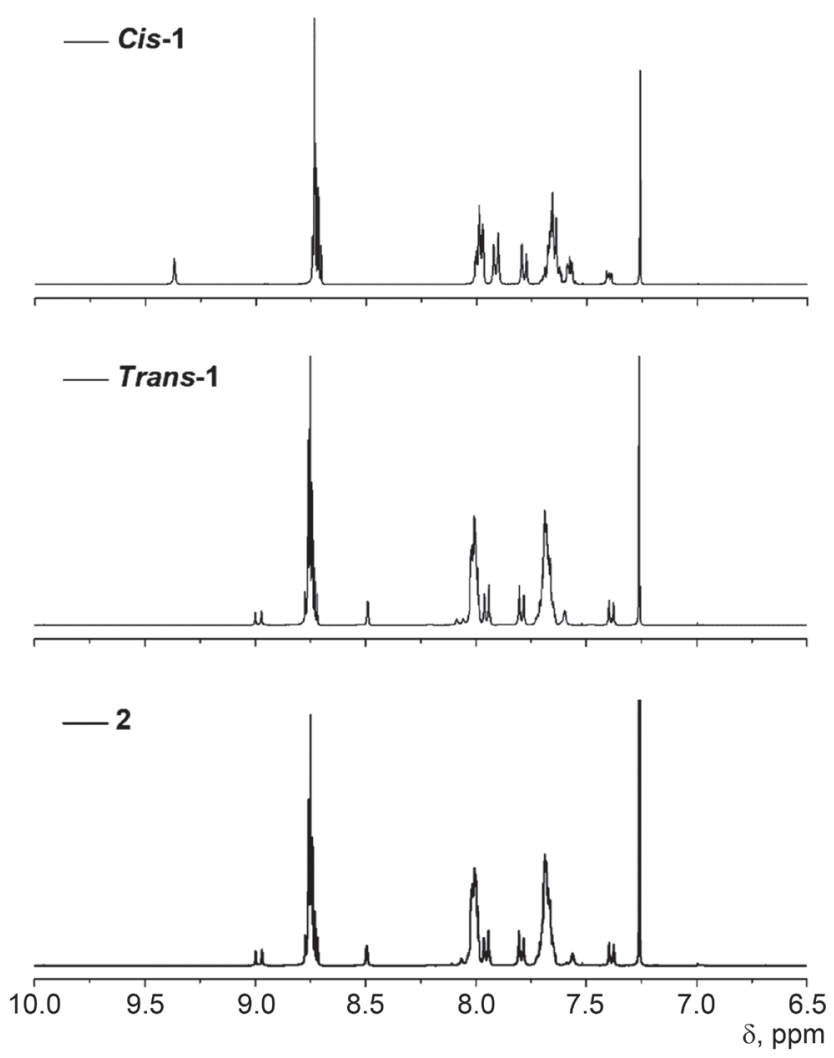

Figure 1. ${ }^{1} \mathrm{H}$ NMR spectra of cis-1 (top), trans-1 (middle) and 2 (bottom) in $\mathrm{CDCl}_{3}$. 
rality. The $B$-band region of the CD spectra of cis-1 spectra exhibits a negative sequence in ascending energy at $416 \mathrm{~nm}$. Additionally, that although the morphologies of the CD signals for the $B$-bands of cis-1, trans-1 are quite similar, but the $\Delta \varepsilon$ value (CD intensity) of cis-1 is significantly larger than trans-1 structure in the manner that would be anticipated based on the larger effect that is in the MO energies. Considering the current porphyrins don't contain any chiral linkage or asymmetric center, there is no coupling between transitions associated with the chiral bridging moiety and the $B$-transition of the porphyrin $\pi$-system, so it is reasonable to assume that exciton coupling between the porphyrin rings is the main mechanism for generating the CD signal. The relative arrangement of the two porphyrin rings of cis-1 and trans-1 can be assigned based


Figure 2. UV-Vis and CD spectra of cis-1 (top), trans-1 (middle) and 2 (bottom) in $\mathrm{CHCl}_{3}$. on the observed sign sequences as favoring structures with the certain anticlockwise twists. Also, the dihedral angle between two porphyrin rings of cis-1 could be expected more approximate to the ideal angle for the coupling compared with trans-1. In contrast, less to no CD signals were observed in the case of $\mathbf{2}$, due to its more flexible molecular structure that caused weak excitation coupling two porphyrin rings. The observed phenomena demonstrate that the CD properties can be facially modulated by changing the interchromophoric through-space coupling distance through both positional isomerism of the bridging diphenylmoiety and its steric hindrance.

\section{Conclusions}

In summary, we have prepared porphyrin dimer with amide-bonded 2,2'- and 4,4'-biphenyl moieties, and the chiral porphyrin dimers could be synthesized and isolated from achiral biphenyl linkage. Both structural and spectroscopic characterizations were performed to in-depth understand the relationship between the enantiomeric molecular structure and inherent chirality. Considering chiral porphyrins have a wide range of application, the current simple modification of optical properties of porphyrin dimers revealed in this research is useful for the design of functional chiral molecules based on achiral linked porphyrins.

Acknowledgements. This work was financially supported by the National Natural Science Foundation of China ( 21701058) the Natural Science Foundation of Jiangsu province ( BK20160499), the State Key Laboratory of Coordination Chemistry (SKLCC1817), the Key Laboratory of Functional Inorganic Material Chemistry (Heilongjiang University) of Ministry of Education, the China post-doc Foundation (2018M642183), the Lanzhou High Talent Innovation.

\section{References}

1. Das S., Bairy G., Jana R. Org. Lett. 2018, 20, 2667.

2. Liu Y., Pak J.K., Schmutz P., Bauwens M., Mertens J., Knight H., Alberto R. J. Am. Chem. Soc. 2006, 128, 15996.

3. Lim H.J., Lee K.H., Kim D.M. Biochem. Eng. J. 2018, 138, 106.

4. Li S.H., Li Z.Y., Park J.O., King C.G., Rabinowitz J.D., Wingreen N.S., Gitai Z. Nat. Microbiol. 2018, 3, 939.

5. Zhang Y.J., Thompson A., Rettig S.J., Dolphin D. J. Am. Chem. Soc. 1998, 120, 13537.

6. Lu H., Kobayashi N. Chem. Rev. 2016, 116, 6184.

7. Watson J.D., Crick F.H.C. Nature 1953, 171, 737-738.

8. Deisenhofer J., Epp O., Miki K., Huber R., Michel H. Nature 1985, 318, 618 .

9. Konishi K., Miyazaki K., Aida T., Inoue S. J. Am. Chem. Soc. 1990, 112, 5639.

10. Guo Y.M., Oike H., Saeki N., Aida T. Angew. Chem. Int. Ed. 2004, 43, 4915.

11. Liang X., Qin M.F., Zhou L., Liu T.T., Li M.Z., Mack J., Ndebeleb N., Nyokong T., Zhu W.H. Dyes Pigm. 2018, 154, 229.

12. Borovkov V.V., Lintuluoto J.M., Fujiki M., Inoue Y. J. Am. Chem. Soc. 2000, 122, 4403.

13. Cheng R.P., Gellman S.H., DeGrado W.F. Chem. Rev. 2001, 101, 3219-3232. 
14. Cornelissen J., Rowan A.E., Nolte R., Sommerdijk N. Chem. Rev. 2001, 101, 4039-4070.

15. Nagata Y., Yamada T., Adachi T., Akai Y., Yamamoto T., Suginome M. J. Am. Chem. Soc. 2013, 135, 10104.

16. Nakano T., Okamoto Y., Hatada K. J. Am. Chem. Soc. 1992 , 114, 1318.

17. Liang X., Shimizu S., Kobayashi N. Chem. Commun. 2014, 50,13781

18. Shang H., Zhao L., Qi D., Chen C., Jiang J. Chem. Eur. J. 2014, 20, 16266.

19. Zhou H., Wang K., Qi D., Jiang J. Dalton. Trans. 2014, 43, 1699.

20. Lv W., Zhu P., Bian Y., Ma C., Zhang X., Jiang J. Inorg. Chem. 2010, 49, 6628 .
21. Li M.Z., Zhang Q., Xu L., Zhu W.H., Mack J., May A.K., Nyokong T., Kobayashi N., Liang X. ChemPlusChem 2017, $82,598$.

22. Jiang J.X., Fang X.S., Liu B.Z., Hu C.J. Inorg. Chem. 2014, 53, 3298.

23. Yoshida N., Ishizuka T., Osuka A., Jeong D.H., Cho H.S., Kim D., Matsuzaki Y., Nogami A., Tanaka K. Chem. Eur. J. 2003, 9, 58 .

24. Liang X., Xu L., Li M.Z., Mack J., Stone J., Nyokong T., Kobayashi N., Zhu W.H. J. Porphyrins Phthalocyanines 2015, 19, 819 .

Received 19.10.2018

Accepted 01.03.2019 